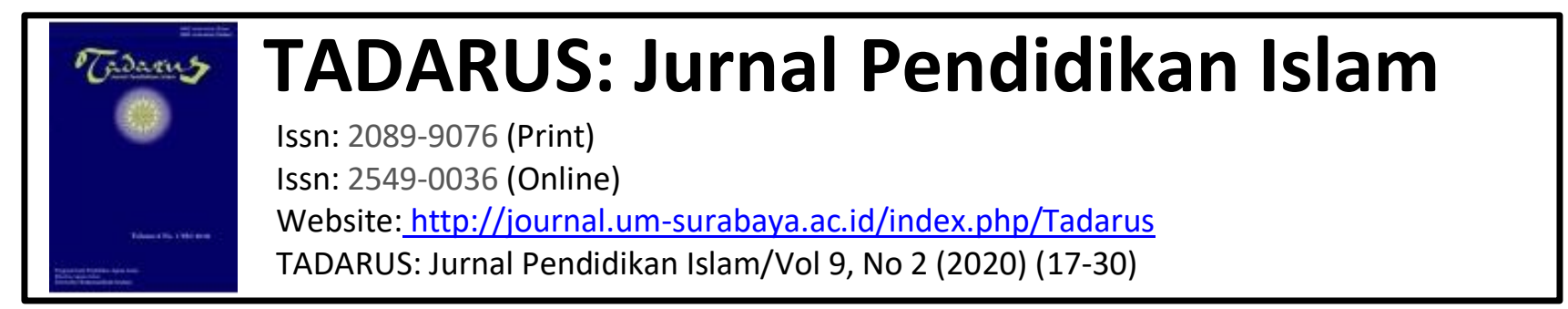

\title{
BIMBINGAN DAN KONSELING ISLAM DENGAN COGNITIVE BEHAVIOR THERAPHY UNTUK MENCEGAH ANXIETY (MASALAH KESEHATAN MENTAL) SEORANG SISWA DI PONDOK PESANTREN ISLAM SALMAN AL-FARISI KARANGANYAR SOLO
}

\author{
${ }^{1}$ Din Muhammad Zakariya, ${ }^{2}$ Muh Iqbal Azhar Aziz \\ 1inmzakariya70@gmail.com, ${ }^{2}$ ikalazhar@gmail.com
}

\begin{abstract}
ABSTRAK
Penelitian ini bertujuan untuk membahas Bagaimana pelaksanaan Bimbingan dan Konseling Islam dengan cognitive behavior therapy (CBT) dalam mencegah masalah kesehatan mental seorang siswa di Pondok Pesantren Islam Salman Al-Farisi Karanganyar Solo? (2) Bagaimana hasil dari siswa setelah menjalani proses Bimbingan dan Konseling Islam dengan cognitive behavior therapy (CBT) dalam mencegah masalah kesehatan mental seorang siswa di Pondok Pesantren Islam Salman Al-Farisi Karanganyar Solo. Penelitian ini menggunakan penelitian kualitatif dengan analisis deskriptif. Dalam menganalisis Bimbingan dan Konseling Islam ini dengan Cognitive Behavior Therapy dalam mencegah masalah kesehatan mental seorang siswa di Pondok Pesantren Islam Salman Al-Farisi Karanganyar Solo, data yang disajikan dalam bab ini penyajian data berupa hasil wawancara dan observasi. Pada penelitian ini disimpulkan bahwa masalah kesehatan mental (anxiety) yang dialami seorang siswa adalah sangat mempengaruhi kondisi kejiwaan dan fisik klien, dari pengamatan konselor sebelum melakukan proses konseling, masalah yang dialami seorang siswa tersebut adalah sering mengalami depresi dan kecemasan yang telah dialaminya. Dalam menangani masalah kasus ini konselor menggunakan Cognitive behavioral therapy, proses konseling menggunakan wawancara (tatap muka dengan klien) dengan mengarahkan bagaimana berfikir yang positif dan berperilaku yang baik. Dengan merubah sikap atau perilaku klien. Hasil akhir dari proses konseling ini dapat dilihat dari adanya perubahan sikap klien atau perilaku klien yang kurang baik sehingga menjadi lebih baik.
\end{abstract}

Kata kunci : Bimbingan, Konseling, dan Anxiety

\section{Pendahuluan}

Ridwan menyatakan, kenyataan menujukkan bahwa umat Islam di Indonesia merupakan mayoritas (85\%). Bagi umat Islam, pemahaman agama beserta pendekatan yang islami terhadap setiap aspek kegiatan merupakan suatu jalan untuk mengamalkan ajaran Islam. Hidup yang islami merupakan cita-cita tertinggi bagi 
setiap pemeluk islami. Pemecahan masalah kehidupan melalui pendekatan yang islami merupakan alternatif jalan keluar yang terbaik baginya demikian juga, setiap kebutuhan hidupnya akan diusahakan dipenuhi lewat pendekatan yang Islami. Berdasarkan kenyataan ini, bimbingan yang dilaksanakan berdasarkan Islam dengan unit analysis need assessment. Kaum humanis (Carl Roger) berpendapat, pendekaan dengan memperhatikan subyektivitas terbimbing akan lebih berhasil dari pada memandang si terbimbing sebagai objek.

Musnar mengemukakan, Sejak nenek moyangnya, bangsa Indonesia, khususnya umat Islam, dikenal sebagai umat yang religius. Sebagai realisasi dari sifat yang religius tersebut maka setiap perilakunya selalu didasarkan pada muatanmuatan religius. Oleh karena itu, bimbingan konseling dengan pendekatan Islami akan lebih bermakna dan sangat vital di bandingkan dengan pendekatan sekuler atau Barat. ${ }^{1}$ Di sinilah letak pentingnya penggalian konsep Bimbingan dan Konseling Islami. Bimbingan dan Konseling Islami dipandang lebih cocok dan sesuai dengan keyakinan hidup agama dibangsa Indonesia, sehingga diharapkan dapat memberikan layanan yang lebih bermanfaat dan efektif bagi subjek.

Menurut fitrahnya, manusia adalah mahluk beragama (homo religius), yaitu mahluk yang memiliki rasa keagamaan dan kemampuan untuk memahami serta mengamalkan nilai-nilai agama. Kefitrahanya adalah yang membedakan manusia dengan binatang serta yang mengangkat harkat dan martabatnya atau kemulian disisi Tuhan. Dengan mengamalkan ajaran agama, berati manusia telah mewujudkan jati dirinya, identitas dirinya (self identity) yang hakiki, yaitu sebagai 'abdullah (hamba Allah) dan khalifatullah (khalifah Allah) di muka bumi.

Dapat disimpulkan bahwa Bimbingan dan Konseling Islami dan agama mempunyai pengaruh yang sangat besar terhadap kesehatan mental individu. Dengan demikian dapatlah dikatakan individu akan mencapai atau memiliki mental yang sehat dengan agama. Seperti yang kita ketahui remaja berada pada tahap kehidupan yang melibatkan mempelajari cara-cara berpikir dan berperilaku baru agar dapat menghadapi berbagai kejadian secara adaptif.

Keyes mengemukakan Sebagai contoh, meskipun 20 persen remaja didiagnosis sakit mental sebelum usia 18 tahun, ini mengisyaratkan bahwa 80 persen

\footnotetext{
${ }^{1}$ Saring Marsudi, Layanan Bimbingan Konseling Di Sekolah, (Muhammadiyah University Press, Surakarta 2010), 51
} 
sisanya sehat secara mental. ${ }^{2}$ Keyes menemukan bahwa hanya 40 persen remaja sehat secara mental dan presentase ini menurun semakin pertambahan umur (15-18 tahun). Berapa pun kurangnya dari kesehatan mental total akan mengakibatkan peningkatan dan menjadi beban bagi diri sendiri dan masyarakat. Oleh sebab itu, mewujudkan kesahatan mental dianggap sebagai tujuan yang pantas dicapai dan berkaitan dengan hasil-hasil positif di banyak bidang, termasuk perilaku sehat, kinerja pendidikan dan mengurangi kriminalitas. Jelas bahwa salah satu faktor kunci dalam membangun resiliensi adalah mengidentifikasi dan mengembangkan kekuatan-kekuatan individu dan kekuatan di dalam seluruh system (keluarga, sekolah, masyarakat, dan sebagainya).

Ahli jiwa membuktikan bahwa salah satu akibat terjadinya gangguan jiwa adalah ketidakberhasilan seseorang dalam memenuhi kebutuhannya. Hal ini akan menyebabkan timbulnya perasaan gelisah dan terganggunya emosi seseorang. Dalam ajaran agama dikenal juga hawa nafsu dibawah sadar tidak mengenal batas, hukum, peraturan atau kaidah-kaidah sosial. Maka agama sebagai pengendali hawa nafsu menentukan batas-batas yang tidak boleh di langgar. ${ }^{3}$ Mengenai keimanan kepada Tuhan dan pengalaman ajaran-Nya dengan kesehatan mental, dalam AlQuran banyak yang menunjukkan bahwa untuk mencapai insan kamil harus benarbenar sinergis antara agama dan 3kehidupan, sebagaimana seperti dalam firman Allah Swt yang bermaksud, Surat At-tiin mengisyaratkan bahwa "manusia akan mengalami kehidupan yang hina/jatuh martabatnya termasuk juga psikologis yang tidak nyaman (mentalnya tidak sehat), kecuali orang-orang yang beriman dan beramal shaleh (berbuat kebajikan)".

Sebagaimana salah satu fenomena yang ada, pada kasus yang peneliti temukan di Pondok Pesantren Islam Salman Al-Farisi Karanganyar Solo ada seorang siswa yang berusia 16 tahun yang mengalami permasalahan dalam hidupnya yang mana siswa tersebut bingung dengan permasalahan keluarganya yang mengalami perceraian orang tuanya, ayah dan ibunya berpisah dan siswa ini merupakan anak tunggal dari keluarga yang berada. Semenjak SD dan SMP dia selalu di sekolahkan di sekolah fullday karena kedua orang tuanya yang sibuk bekerja sebagai dokter,

\footnotetext{
${ }^{2}$ Kathryn Geldard, Konseling Remaja Intervensi Praktis Bagi Remaja Beresiko, (Pustaka Belajar, yogyakarta 2012), 40

${ }^{3}$ Yusak Burhanuddin, Kesehatan Mental (CV. Pustaka Ceria, bandung 1999), 104-105
} 
sehingga ia juga mengalami kurangnya kasih sayang terhadap orang tua, semenjak masuk bangku MA ia dipondokan oleh kedua orang tuanya di Pondok Pesantren Islam Salman Al-Farisi Karanganyar Solo dan juga bersekolah di Pondok Pesantren.

Semenjak masuk di Pondok Pesantren tersebut siswa ini merasa ada tekanan pada dirinya karena dibandingkan dengan hidup dirumahnya jauh lebih berbeda, karena di dalam Pondok Pesantren Islam Salman Al-Farisi banyak sekali aktivitas atau kegiatan yang di pondok yang harus di lakukan mulai dari bangun jam 3 pagi sampai dengan jam 10 malam waktu tidur, apalagi setiap santri/siswanya tidak diperbolehkan untuk keluar pondok pesantren tampa seijin ustadz pondok. Ini yang menjadi siswa tersebut mengalami guncangan depresi yang cukup hebat apalagi ia sendiri belum terbiasa hidup dengan banyaknya aturan, selain itu ia juga memikirkan hidupnya nanti kedepanya yang sedang mengalami permasalahan hidup akibat perceraian kedua orang tuanya ia binggung harus memilih siapa nantinya, apakah ia harus tinggal bersama ayah atau ibunya karena ayahnya saat ini sudah menikah lagi dengan istri barunya dan ibunya sudah menikah lagi dengan suami barunya apalagi kedua orang tuanya jarang menjenguknya ketika ia sedang berada di Pondok Pesantren Islam Salman Al-Farisi Karanganyar Solo, sehingga didalam hatinya ia merasa iri ketika waktu hari minggu semua teman-temanya dijenguk oleh orang tuanya. Dan ia juga kebinguangan setelah lulus sekolah ia bingung untuk memilih prospek karirnya, ia sendiri ingin menjadi pengusaha perminyakan di kalimantan dan ingin sekali melanjutkan kuliah di PTU, sedangakan ia juga diarahkan oleh orang tuanya untuk memilih kedokteran yang seperti pekerjaan dari kedua orang tuanya. Sedangkan dari diri siswa sendiri belum berminat untuk memilih jurusan kedokteran. Hal ini menambah gejala ganguan mental pada seorang siswa tersebut yang mengakibatkan terguncang mentalnya. Oleh karena itu siswa ini perlu Bimbingan dan Konseling Islami dengan Cognitive Behavior Therapy (CBT) di mana agar siswa ini dapat memecahkan masalahnya agar tidak mengalami gejala kesehatan mental di usianya yang 16 tahun saat ini. Setelah melihat fenomena di atas maka penulis tertarik untuk melakukan penelitian yang berjudul "Bimbingan dan Konseling Islam dengan Cognitive Behavior Therapy (CBT) dalam Mencegah Masalah Kesehatan Mental (ANXIETY) Seorang Siswa di Pondok Pesantren Islam Salman Al-Farisi Karanganyar Solo" 


\section{Metode Penelitian}

Dalam penelitian ini, peneliti menggunakan penelitian kualitatif. Penelitian kualitatif adalah metode penelitian yang berlandaskan pada filsafat postpositivisme, digunakan untuk meneliti pada kondisi objek yang alamiah, di mana peneliti adalah sebagai instrumen kunci, teknik pengumpulan data dilakukan secara triangulasi (gabungan), analisis data bersifat induktif/kualitatif. ${ }^{4}$

Peneliti menggunakan pendekatan kualitatif dikarenakan data-data yang didapatkan nantinya adalah data kualitatif berupa kata-kata atau tulisan tidak berbentuk angka dan untuk mengetahui serta memahami fenomena secara terinci, mendalam, dan menyeluruh.

Sedangkan jenis penelitian yang digunakan adalah studi kasus. Studi kasus adalah uraian dan penjelasan komprehensif mengenai berbagai aspek seorang individu, suatu kelompok, suatu organisasi (komunitas) atau situasi sosial. Peneliti studi kasus berupaya menelaah sebanyak mungkin data mengenai subjek yang diteliti. $^{5}$

\section{Hasil Penelitian dan Pembahasan}

\section{Cognitive Behavior Therapy}

a. Pengertian Cognitive Behavior Therapy

Terapi kognitif behavioral adalah terapi yang mempergunakan gabungan antara tiga pendekatan yaitu biomedik, intrapsikik dan lingkungan. Dalam melakukan terapi dengan teknik ini banyak mempergunakan prosedur dasar untuk melakukan perubahan kognitif dan perilaku, misal seperti: pengamatan diri, kontrak dengan diri sendiri, dan artian lebih luas teknik ini mengajarkan keterampilan kepada klien dalam menghadapi suasana yang menimbulkan kegoncangan dikemudian hari.

Terapi ini didasarkan pada teori bahwa efek keadaan emosi, perasaan dan tindakan seseorang, sebagian besar ditentukan oleh bagaimana seseorang tersebut membentuk dunianya, jadi bagaimana seseorang berfikir, menentukan bagaimana perasaan dan reaksinya. Pikiran seseorang memberikan gambaran tentang rangkaian kejadian didalam kesadarannya. Gejala perilaku yang berkelainan atau menyimpang,

\footnotetext{
${ }^{4}$ Sugiyono, Metode Penelitian Kuantitatif, Kualitatif dan $R \&$ D, (Alfabeta: Bandung, 2009), 9.

${ }^{5}$ Deddy Mulyana, Metode Penelitian Kualitatif, (Bandung: Remaja Rosdakarya, 2002), 201.
} 
berhubungn erat dengan isi pikiran, misalnya seorang menderita ansiestas atau gangguan kecemasan, ketakutan, kekuwatiran yang kuat karena mengantisipasi akan mengalami hal-hal yang tidak enak pada dirinya. Dalam hal seperti ini, kognitif behavioral dipergunakan untuk mengidentifikasi, memperbaiki perilaku yang sesuai, dan fungsi kognisi yang terhambat, yang mendasari aspek kognitifnya yang ada. Terapis dengan pendekatan kognitif behavior mengajar klien agar berpikir lebih realistic dan sesuai sehingga dengan demikian akan mengilangkan atau mengurangi gejala yang berkelainan yang ada. ${ }^{6}$

Dari sudut Cognitive Behavior, Manusia sebagai "bukan benda atau hal yang menyulitkan kita, namun cara memandang kita terhadap benda atau hal tersebut." Kelompok ini menitik beratkan bahwa setiap orang dapat menyusun arti yang khusus atau memikirkan tentang suatu kejadian. Tingkatan pada mana seseorang berada dalam penguasaan berpikirnya, tergantung dari teorinya yang dipergunakan, namun kesemuanya akan menitik beratkan pada tindakan dan perilaku yang berkaitan dengan kognisi yang dimiliki.

Corey merumuskan pandangan terhadap manusia dari sudut kelompok kognitif behavioristik, manusia dilahirkan dengan kemampuan untuk berpikir rasional, tetapi juga dengan kecenderungan untuk berfikir "tidak lurus" mereka cenderung untuk percaya kepada hal-hal yang tidak rasional dan untuk menanamkan kepercayaan ini terhadap diri sendiri.

\section{b. Sejarah Cognitive Behavior Therapy}

Perkembangan pendekkatan behavior di awali pada tahun 1950-an dan awal 1960-an sebagai awal radikal menentang perspektif psikoanalisis yang dominan. Pendekatan ini di hasilkan berdasarkan hasil eksperimen para behaviorist yang memberikan sumbangan pada prinsip-prinsip belajar dalam tingkah laku manusia. Pendekatan ini memiliki perjalanan panjang mulai dari penelitian laboratorium terhadap binatang hingga eksperimen terhadap manusia. Secara garis besar, sejarah perkembangan pendekatan behavioral terdiri dari tiga trend utama, Yaitu: trend I: kondisioning klasik (classical conditioning), trend II: kondisioning operant (operant conditioning), dan trend III: terapi kognitif (cognitive therapy). ${ }^{7}$

\footnotetext{
${ }^{6}$ Singgih D. Gunarsah, Konseling dan Psikoterapi (Jakarta, PT. BPK Gunung Mulia 2000), 227

${ }^{7}$ Gantina Komalasari, Eka wahyuni \& Karsih, Teori dan Teknik Konseling (Jakarta: PT. INDEKS, 2011), 141-142.
} 
Penerapan terapi kepada klien dengan berbagai gangguan klinis psikologis telah banyak dipermasalahkan sejak awal munculnya psikoterapi. Kasus klasik Anna O. Yang ditangani dengan aliran Freudian dan kasus Manusia Tikus ${ }^{8}$ merupakan salah satu contoh penggunaan psikoterapi pada kasus gangguan kepribadian. Dengan perkembangan Diagnostic And Statistical Manual of Disorder (DSM) I hingga IV, juga Pedoman Penggolongan Diagnostik gangguan Jiwa (PPDGJ), definisi dan parameter untuk memahami kondisi kronis penyimpangan-penyimpangan klinis ini menjadi semakin berkembang pula.

Berbagai bentuk yang berbeda tentang Cognitive Behavior Therapy dikembangkan oleh beberapa ahli, anatara lain Albert Ellis dengan Rational Emotive Therapy, Aaron T, Beck dengan Cognitive Behavior Therapy tahun 1964, Donald Meichenbaum dengan Cognitive Behavior Modification, 1977, dan Arnold Lazarus dengan Multimodal Therapy, 1976. Sumbangan yang tidak kalah berharga diberikan pula oleh Michael Mahoney 1991, Vittorio Guidano dan Giovanni Liotti 1983. ${ }^{9}$

Aaron Beck, menyebut aliran teorinya sebagai Cognitive Therapy (CT), dimana ia mengembangkan teori ini pada kasus-kasus depresi yang kemudian berkembang pada kasus kecemasan dan phobia, serta berlanjut pada kasus-kasus gangguan kepribadian. Cognitive Therapy dari Beck ini memiliki banyak kesamaan dengan Rational Emotive Therapy, dalam hal pendekatan aktif, direktif, terpusat pada masa kini, dan tersruktur. Ia menekankan upaya terapi pada teknik mengenali dan merubah pikiran negatif sekaligus sistem kepercayaan yang maladaptif (kaku). Pendekatan Beck didasarkan kepada pemikiran logis bahwa cara seseorang merasa dan bertindak sangat dipengaruhi oleh cara ia memandang dan memahami pengalamanya. Tujuan utama Cognitive Therapy adalah untuk merubah cara pandang klien melalui pikiran otomatisnya dan memberi ide untuk merestrukturisasi pikiran negatif dan system kepercayaan yang baku.

c. Tujuan Cognitive Behavior Therapy

Tujuan Cognitive Behavior Therapy adalah untuk mengajak klien untuk menentang pikiran (dan emosi) yang salah dengan menampilkan bukti-bukti yang bertentangan dengan keyakinan mereka tentang masalah yang dihadapi. Terapis diharapkan mampu menolong klien untuk mencari keyakinan yang sifatnya

\footnotetext{
${ }^{8}$ BECK, Aaron T, Arthur Freeman \& Associates, Cognitive Therapy of Personality, 1990.

${ }^{9}$ BECK, Judith S., Cognitive Therapy: Basics and Beyond (New York: The Guilford Press, 1995).
} 
dogmatis dalam diri klien dan secara kuat mencoba menguranginya. Terapis harus waspada terhadap munculnya pemikiran yang tiba-tiba mungkin dapat dipergunakan untuk merubah mereka.

Dalam proses ini, beberapa ahli Cognitive Behavior memiliki pendapat bahwa masa lalu tidak perlu menjadi fokus penting dalam terapi, karenanya Cognitive Behavior lebih banyak bekerja pada status kognitif masa kini untuk dirubah dari negatif menjadi positif. Sementara sebagian ahli lain berusaha menghargai masa lalu sebagai bagian dari hidup klien dan mencoba membuat klien menerima masa lalunya, untuk tetap melakukan perubahan pada pola pikir masa kini demi mencapai perubahan untuk masa yang akan datang.

\section{d. Teknik-teknik Cognitive Behavior Therapy}

Berbagai variasi teknik perubahan kognisi, emosi dan tingkah laku menjadi sarana psikoterapi yang penting dalam Cognitive Behavior. Metode ini berkembang sesuai kebutuhan klien, dimana terapis bersikap aktif, direktif, terbatas waktu, berstruktur, dan berpusat pada masa kini. Teknik ini menyanggah keyakinan irrasional klien dengan menggunakan pekerjaan rumah, mengumpulkan data asumsi-asumsi negatif, mencatat aktivitas, membentuk interpresi yang berbeda, belajar keahlian menyelesaikan masalah, merubah pola pikir dan pola bicara, berimajinasi, dan secara kuat menentang keyakinan yang salah.

Teknik konseling behavior terdiri dari dua jenis, yaitu teknik untuk menikmati tingkah laku dan untuk menurunkan tingkah laku. Teknik untuk meningkatkan tingkah laku antara lain: penguatan positif, token economy, pembentukan tingkah laku (shaping), pembentukan kontrak (contingency contracting), sedangkan tekknik konseling untuk menurunkan tingkah laku adalah: penghapusan (extinction), timeout, pembanjiran (flooding), penjenuhan (satiation), hukuman (punishment), terapi aversi (aversive therapy), dan disensitinasi sistematis. ${ }^{10}$

e. Jenis Pendekatan Cognitive Behavior Therapy

Cognitive Behavior Therapy mendasarkan pada penggabungan antara tiga pendekatan yaitu: ${ }^{11}$

1) Biomedik adalah membentuk pola pikir seeorang yang logis, kreatif dan inofatif.

${ }^{10}$ Gantina Komalasari, Eka wahyuni \& Karsih, Teori dan Teknik Konseling (Jakarta: PT. INDEKS, 2011), 161.

${ }^{11}$ Singgih D. Gunarsah, Konseling dan Psikoterapi (Jakarta, PT. BPK Gunung Mulia 2000), 228 
2) Intrapsikik yaitu merupakan proses dimana upaya-upaya yang tidak disadari dicegah berkaitan dengan kesadaran.

3) Lingkungan yaitu setiap manusia mempunyai hubungan dengan orang-orang atau masyarakat untuk berperilaku dan komunikasi.

Dengan melakukan terapi dengan teknik ini banyak mengunakan prosedur dasar untuk melakukan perubahan perilaku misal seperti, pengamatan diri, kontrak dengan diri sendiri, latihan relaksasi dan pengebalan sistematik. Kecuali itu teknik ini mempergunakan pendekatan untuk mengajarkan keterampilan kepada klien dalam menghadapi suasana yang menimbulkan kegoncangan dikemudian hari.

f. Fungsi Cognitive Behavior Therapy

Cognitive Behavior Therapy merupakan terapi yakni, menghilangkan cara berpikir yang menyalakan diri sendiri, mengembangkan cara memandang lebih rasional dan toleran terhadap diri sendiri dan orang lain. Perilaku yang nyata berdasarkan cara berpikir seperti itu. Core merumuskan mengenai fungsi Cognitive Behavior Therapy, bahwa terapi tersebut menghilangkan cara memandang dalam kehidupan pasien yang menyalahkan diri sendiri dan membantunya memperoleh pandangan dalam hidup secara lebih rasional dan toleran.

g. Prinsip-Prinsip Cognitive Behavior Therapy

Walaupun konseling harus disesuaikan dengan karakteristik atau permasalahan konseli, tentunya konselor harus memahami prinsip-prinsip yang mendasari CBT. Pemahaman terhadap prinsip-prinsip ini diharapkan dapat mempermudah konselor dalam memahami konsep, strategi dalam merencanakan proses konseling dari setiap sesi, serta penerapan teknik-teknik CBT. Berikut adalah prinsip-prinsip dasar dari CBT berdasarkan kajian yang diungkapkan oleh Beck:

Prinsip nomor 1: Cognitive-Behavior Therapy didasarkan pada formulasi yang terus berkembang dari permasalahan konseli dan konseptualisasi kognitif konseli. Formulasi konseling terus diperbaiki seiring dengan perkembangan evaluasi dari setiap sesi konseling. Pada momen yang strategis, konselor mengkoordinasikan penemuan-penemuan konseptualisasi kognitif konseli yang menyimpang dan meluruskannya sehingga dapat membantu konseli dalam penyesuaian antara berfikir, merasa dan bertindak.

Prinsip nomor 2: Cognitive-Behavior Therapy didasarkan pada pemahaman yang sama antara konselor dan konseli terhadap permasalahan yang dihadapi 
konseli. Melalui situasi konseling yang penuh dengan kehangatan, empati, peduli, dan orisinilitas respon terhadap permasalahan konseli akan membuat pemahaman yang sama terhadap permasalahan yang dihadapi konseli. Kondisi tersebut akan menunjukan sebuah keberhasilan dari konseling.

Prinsip nomor 3: Cognitive-Behavior Therapy memerlukan kolaborasi dan partisipasi aktif. Menempatkan konseli sebagai tim dalam konseling maka keputusan konseling merupakan keputusan yang disepakati dengan konseli. Konseli akan lebih aktif dalam mengikuti setiap sesi konseling, karena konseli mengetahui apa yang harus dilakukan dari setiap sesi konseling.

Prinsip nomor 4: Cognitive-Behavior Therapy berorientasi pada tujuan dan berfokus pada permasalahan. Setiap sesi konseling selalu dilakukan evaluasi untuk mengetahui tingkat pencapaian tujuan. Melalui evaluasi ini diharapkan adanya respon konseli terhadap pikiran-pikiran yang mengganggu tujuannya, dengan kata lain tetap berfokus pada permasalahan konseli.

Prinsip nomor 5: Cognitive-Behavior Therapy berfokus pada kejadian saat ini. Konseling dimulai dari menganalisis permasalahan konseli pada saat ini dan di sini (here and now). Perhatian konseling beralih pada dua keadaan. Pertama, ketika konseli mengungkapkan sumber kekuatan dalam melakukan kesalahannya. Kedua, ketika konseli terjebak pada proses berfikir yang menyimpang dan keyakinan konseli dimasa lalunya yang berpotensi merubah kepercayaan dan tingkahlaku ke arah yang lebih baik.

Prinsip nomor 6: Cognitive-Behavior Therapy merupakan edukasi, bertujuan mengajarkan konseli untuk menjadi terapis bagi dirinya sendiri, dan menekankan pada pencegahan. Sesi pertama CBT mengarahkan konseli untuk mempelajari sifat dan permasalahan yang dihadapinya termasuk proses konseling cognitive-behavior serta model kognitifnya karena CBT meyakini bahwa pikiran mempengaruhi emosi dan perilaku. Konselor membantu menetapkan tujuan konseli, mengidentifikasi dan mengevaluasi proses berfikir serta keyakinan konseli. Kemudian merencanakan rancangan pelatihan untuk perubahan tingkah lakunya.

Prinsip nomor 7: Cognitive-Behavior Therapy berlangsung pada waktu yang terbatas. Pada kasus-kasus tertentu, konseling membutuhkan pertemuan antara 6 sampai 14 sesi. Agar proses konseling tidak membutuhkan waktu yang panjang, diharapkan secara kontinyu konselor dapat membantu dan melatih konseli untuk 
melakukan self-help.

Prinsip nomor 8: Sesi Cognitive-Behavior Therapy yang terstruktur.Struktur ini terdiri dari tiga bagian konseling. Bagian awal, menganalisis perasaan dan emosi konseli, menganalisis kejadian yang terjadi dalam satu minggu kebelakang, kemudian menetapkan agenda untuk setiap sesi konseling. Bagian tengah, meninjau pelaksanaan tugas rumah (homework asigment), membahas permasalahan yang muncul dari setiap sesi yang telah berlangsung, serta merancang pekerjaan rumah baru yang akan dilakukan. Bagian akhir, melakukan umpan balik terhadap perkembangan dari setiap sesi konseling. Sesi konseling yang terstruktur ini membuat proses konseling lebih dipahami oleh konseli dan meningkatkan kemungkinan mereka mampu melakukan self-help di akhir sesi konseling.

Prinsip nomor 9: Cognitive-Behavior Therapy mengajarkan konseli untuk mengidentifikasi, mengevaluasi, dan menanggapi pemikiran disfungsional dan keyakinan mereka. Setiap hari konseli memiliki kesempatan dalam pikiran-pikiran otomatisnya yang akan mempengaruhi suasana hati, emosi dan tingkah laku mereka. Konselor membantu konseli dalam mengidentifikasi pikirannya serta menyesuaikan dengan kondisi realita serta perspektif adaptif yang mengarahkan konseli untuk merasa lebih baik secara emosional, tingkah laku dan mengurangi kondisi psikologis negatif. Konselor juga menciptakan pengalaman baru yang disebut dengan eksperimen perilaku. Konseli dilatih untuk menciptakan pengalaman barunya dengan cara menguji pemikiran mereka (misalnya: jika saya melihat gambar labalaba, maka akan saya merasa sangat cemas, namun saya pasti bisa menghilangkan perasaan cemas tersebut dan dapat melaluinya dengan baik). Dengan cara ini, konselor terlibat dalam eksperimen kolaboratif. Konselor dan konseli bersama-sama menguji pemikiran konseli untuk mengembangkan respon yang lebih bermanfaatdan akurat.

Prinsip nomor 10: Cognitive-Behavior Therapy menggunakan berbagai teknik untuk merubah pemikiran, perasaan, dan tingkah laku. Pertanyaan-pertanyaan yang berbentuk sokratik memudahkan konselor dalam melakukan konseling cognitive-behavior. Pertanyaan dalam bentuk sokratik merupakan inti atau kunci dari proses evaluasi konseling. Dalam proses konseling, CBT tidak mempermasalahkan konselor menggunakan teknik-teknik dalam konseling lain seperti kenik Gestalt, Psikodinamik, Psikoanalisis, selama teknik tersebut membantu 
proses konseling yang lebih singkat dan memudahkan konselor dalam membantu konseli. Jenis teknik yang dipilih akan dipengaruhi oleh konseptualisasi konselor tehadap konseli, masalah yang sedang ditangani, dan tujuan konselor dalam sesi konseling tersebut.

\section{Analisis Data}

Berdasarkan masalah yang terjadi pada seorang siswa yang baru berusia enam belas tahun, yang masih duduk di bangku kelas satu MA. Maka konselor memilih Cognitive Behavior Therapy untuk melakukan proses terapi konseling. Cognitive behavior adalah teori yang mengunakan tiga pendekatan yaitu biodemik, intrapsikik dan lingkungan. Teori ini mengajarkan keterampilan kepada klien untuk menentukan bagaimana perasaan dan reaksi klien dan pikiran seorang klien memberikan gambaran tentang rangkaian kejadian didalam kesadarannya.

Cognitive Behavioral Therapy (CBT) merupakan salah satu pendekatan psikoterapi yang paling banyak diterapkan dan telah terbukti efektif dalam mengatasi berbagai gangguan, termasuk kecemasan dan depresi. Asumsi yang mendasari Cognitive Behavioral Therapy, terutama untuk kasus depresi yaitu bahwa gangguan emosional berasal dari distorsi (penyimpangan) dalam berpikir. Perbaikan dalam keadaan emosi hanya dapat berlangsung lama kalau dicapai perubahan polapola berpikir selama proses terapi. Demikian pula pada klien pola berpikir yang maladaptive (disfungsi kognitif) dan gangguan perilaku. Dengan memahami dan merubah pola tersebut, klien diharapkan mampu melakukan perubahan cara berpikirnya dan mampu mengendalikan gejala-gejala dari gangguan yang dialami.

\section{Analisis Hasil Akhir}

Dalam analisis hasil akhir dari pelaksanaan bimbingan dan konseling Islam untuk mengetahui hasil terapi yang di lakukan, maka konselor memperoleh dari pengamatan aktivitas sehari-hari dan wawancara klien yang di mana klien yang semula suka melamun, cemas, depresi, dan panik dalam aktivitas kehidupan seharihari. Konselor membandingkan apakah ada perubahan pada diri klien setelah proses konseling dan sebelum proses konseling dilakukan, selain itu konselor melakukan pengamatan dan wawancara pada anak sebagai klien lain dan hasil dari pelaksanaan konseling dengan Cognitive Behavior Therapy ini digunakan apa ada perubahan dari 
kondisi yang lebih baik dari pada kondisi awal sebelumnya, maka dari teknik ini efektif untuk dilakukan dalam menagani kasus masalah kesehatan mental seorang siswa.

Sebelum pada tahap proses konseling klien mengalami gejala suka melamun, merasa cemas, depresi, dan panik. Kemudian konselor melakukan proses konseling pada klien tersebut, setelah melakukan proses konseling klien mengalami perubahan, klien saat ini sudah tidak mulai mengalami masalah kecemasan, melamun, depresi, dan merasakan kepanikan, dan klien sudah mau bersekolah dengan antribut sekolah yang lengkap, datang tepat waktu, lebih aktif bertanya di dalam kelas.

Dari penjelasan di atas, dapat terlihat bahwa setelah melakukan proses konseling dengan Cognitive Behavior Therapy yang dilakukan membawa perubahan yang baik pada diri klien. Yang dimana klien setiap sekolah sering terlambat, suka melamun di dalam kelas, pendiam, sekarang klien bisa berubah dengan datang kesekolah tepat waktu dengan memakai antribut sekolah lengkap, lebih aktif bertanya di dalam kelas, lebih suka berbaur dengan teman-temannya, mengisi waktu luang atau kosong di dalam kelas dengan mengaji menghafal surat-surat Al-Quran, dan berolahraga sesui dengan hobi dan bakatnya.

Dari hasil akhir pelaksanaan Bimbingan dan Konseling Islam ini sudah terlihat bahwa dengan teknik cognitive behavior bisa membawa perubahan kepada klien yakni dalam mencegah masalah kesehatan mental (anxiety) secara perlahan-lahan. Ini disebabkan faktor perubahan yang nampak dalam diri klien setiap kali berhubungan dengan wawancara atau tatap muka secara langsung. Saat ini kehidupan klien mulai kembali menjadi kepribadian yang lebih baik dari pada yang sebelumnya. Dalam hal ini konselor berharap perubahan yang terjadi pada klien akan bertahan dan semakin lebih baik kedepanya.

\section{Kesimpulan}

Penelitian ini dapat disimpulkan bahwa masalah kesehatan mental (anxiety) yang dialami seorang siswa adalah sangat mempengaruhi kondisi kejiwaan dan fisik klien, dari pengamatan konselor sebelum melakukan proses konseling, masalah yang dialami seorang siswa tersebut adalah sering mengalami depresi dan kecemasan yang telah dialaminya. Dalam menangani masalah kasus ini konselor menggunakan 
Cognitive behavioral therapy, proses konseling menggunakan wawancara (tatap muka dengan klien) dengan mengarahkan bagaimana berfikir yang positif dan berperilaku yang baik. Dengan merubah sikap atau perilaku klien. Hasil akhir dari proses konseling ini dapat dilihat dari adanya perubahan sikap klien atau perilaku klien yang kurang baik sehingga menjadi lebih baik.

\section{DAFTAR PUSTAKA}

Aaron, T BECK (1990), Arthur Freeman \& Associates, Cognitive Therapy of Personality, tt.

Burhanuddin, Yusak (1999), Kesehatan Mental, Bandung: CV. Pustaka Ceria.

Geldard, Kathryn (2012), Konseling Remaja Intervensi Praktis Bagi Remaja Beresiko, Yogyakarta: Pustaka Belajar.

Gunarsah, Singgih D. (2000), Konseling dan Psikoterapi, Jakarta: PT. BPK Gunung Mulia.

Judith, S BECK (1995), Cognitive Therapy: Basics and Beyond, New York: The Guilford Press.

Komalasari, Gantina (2011), Teori dan Teknik Konseling, Jakarta: PT. INDEKS.

Marsudi, Saring (2010), Layanan Bimbingan Konseling Di Sekolah, Suratakarta: Muhammadiyah University Press.

Mulyana, Deddy (2002), Metode Penelitian Kualitatif, Bandung: Remaja Rosdakarya.

Sugiyono (2009), Metode Penelitian Kuantitatif, Kualitatif dan $R \& D$, Bandung: Alfabeta. 